\title{
REVIEW OF THE PAST, PRESENT, AND FUTURE OF THE HYDROMETALLURGICAL PRODUCTION OF NICKEL AND COBALT FROM LATERITIC ORES
}

\author{
Srđan Stanković ${ }^{1 *}$, Srećko Stopić ${ }^{2}$, Miroslav Sokić ${ }^{3}$, Branislav Marković ${ }^{3}$, \\ Bernd Friedrich ${ }^{2}$ \\ ${ }^{1}$ Federal Institute for Geosciences and Natural Resources, Stilleweg 2, \\ 30655 Hannover, Germany \\ ${ }^{2}$ IME Proces Metallurgy and Metal Recycling, RWTH Aachen University, \\ Intzestrasse 3, 52056 Aachen, Germany \\ ${ }^{3}$ Institute for Technology of Nuclear and Other Mineral Raw Materials, \\ Franchet d'Esperey Boulevard 86, 11000 Belgrade, Serbia
}

Received 10.06.2020

Accepted 08.07.2020

\begin{abstract}
Laterite ores are becoming the most important global source of nickel and cobalt. Pyrometallurgical processing of the laterites is still a dominant technology, but the share of nickel and cobalt produced by the application of various hydrometallurgical technologies is increasing. Hydrometallurgy is a less energy-demanding process, resulting in lower operational costs and environmental impacts. This review covers past technologies for hydrometallurgical processing of nickel and cobalt (Caron), current technologies (high-pressure acid leaching, atmospheric leaching, heap leaching), developing technologies (Direct nickel, Neomet) as well as prospective biotechnologies (Ferredox process).
\end{abstract}

Keywords: hydrometallurgy; laterites; nickel; cobalt.

${ }^{*}$ Corresponding author: Srđan Stanković, Srdjan.Stankovic@bgr.de 


\section{Contents}

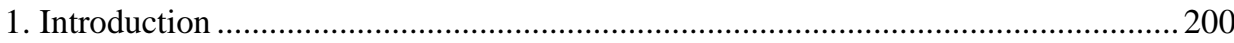

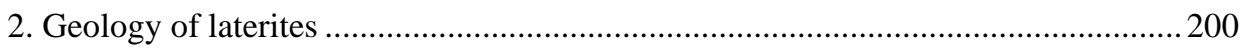

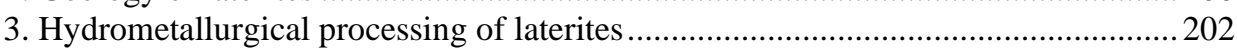

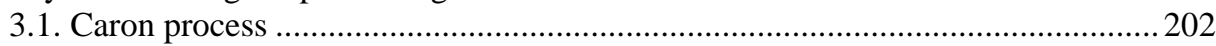

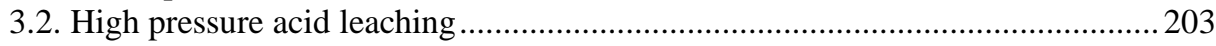

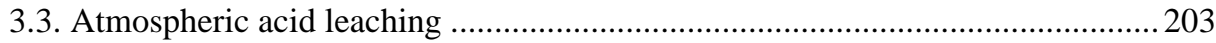

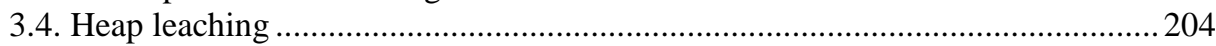

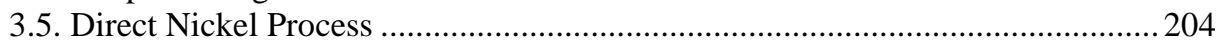

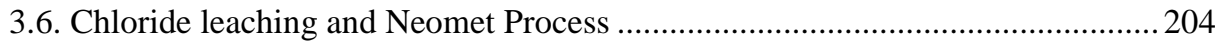

3.7. Reductive bioleaching (Ferredox concept) .................................................. 204

4. Overview of the hydrometallurgical operations for $\mathrm{Ni}$ and Co extraction

from lateritic ores

\section{Introduction}

For many years, the nickel and cobalt were dominantly produced pyrometallurgically from the sulfide ores. The nickel sulfide ores account for approximately $30 \%$ of the global nickel deposits, the rest of the nickel in Earth's crust is contained in laterites - an oxide ores. Nickel production from sulfide ores is reaching a plateau, and a gradual shift to the exploitation of laterites was a logical development. In the 1950s, approximately $90 \%$ of the nickel was produced from sulfide ores; until 2009, nickel production from laterites increased to $50 \%$ of the global production. It is estimated that by $202272 \%$ of nickel will be extracted from lateritic ores [1]. One of the main reasons to favor production of the nickel from sulfide ores over laterites is the inability to produce high-grade mineral concentrates from lateritic ores. Mineral concentrates produced from nickel sulfide ores contain $10-26 \%$ of $\mathrm{Ni}$, while beneficiation of laterite ores results in concentrates with only two-fold and rarely three-fold increase in Ni concentration [2] resulting in mineral concentrates with $3-5 \%$ of $\mathrm{Ni}$. As a consequence, the production of nickel and cobalt from laterites requires significantly larger processing facilities causing more considerable capital costs in comparison to Ni and Co production from sulfide ores. Also, heterogeneous and complex mineralogy of laterites is often an obstacle for achieving satisfactory yields of nickel and cobalt during pyrometallurgical processing. Therefore a hydrometallurgical treatment of lateritic ore is a challenge for the future. Since cobalt belongs to critical metals, a high emphasis is placed on the treatment of lateritic ores present in metallurgical activities.

\section{Geology of laterites}

Laterites are supergene ore bodies formed by chemical and mechanical weathering of the magmatic (ultramafic) rocks. Weathering of the ultramafic rock is influenced by climate, geomorphology, $\mathrm{pH}$, and Eh of the circulating water, tectonics, chemical, and mineralogical composition of the parent rock. The weathering rate varies from 10 to 50 meters per million years [3]. Chemical weathering mobilizes the most soluble elements $(\mathrm{Mg}, \mathrm{Ca}$, and $\mathrm{Si})$ and concentrates the least soluble elements (Fe, Ni, Mg, Zn, Co, Y, Cr, Al, Ti, Cu) [4]. All lateritic ore deposits follow a similar weathering profile. At the bottom of the deposit is an unweathered protolith constituted mainly of 
olivine and pyroxene minerals. Above this is a saprolite layer with hydrous $\mathrm{Mg}$ and $\mathrm{Ni}$ rich silicates (a serpentine group of minerals) and also some lizardite, magnetite, goethite, maghemite, and chromite. Above the saprolite zone is a clay rich zone constituted mostly of nontronite, beidellite, montmorillonite, and saponite minerals. At the top of the laterite deposit is a limonite layer consisted mostly of iron oxides (goethite and hematite) covered with an iron cap (or iron crust). Lateritic ore bodies can be divided into three subtypes [3]:

1. Oxide laterites are mostly constituted of the limonite zone. Limonite zone is formed after hydrolysis of the olivine, pyroxene, and serpentine minerals. The olivine is the first mineral to be hydrolyzed, releasing silicon and $\mathrm{Mg}^{2+}$ ions from the rock matrix. Ferrous iron is also leached from the rock, and then oxidized and precipitated as ferric hydroxide, initially amorphous and then progressively crystalized to form goethite. Nickel and cobalt ions leached from the ultramafic rock have an affinity for the amorphous ferric hydroxides and are incorporated in their structure by a combination of adsorption and replacement of ferric iron. Oxidation of goethite leads to the formation of hematite. Limonite zones in laterites can be divided in two subzones: "yellow limonite" dominated by goethite, and above it "red limonite" dominated be hematite. The Limonite zone is covered with iron crust.

2. Clay laterites are formed in colder and drier climates. In these conditions, silica is not leached from the rock matrix as in the humid tropical areas. The $\mathrm{Ni}$ and Co are concentrated in the zone dominated by smectite clay nontronite. In the nontronite crystal lattice, $\mathrm{Fe}^{2+}$ ions can be substituted by nickel ions. Clay laterites typically contain $1.0-1.5 \%$ of nickel.

3. Silicate laterites are formed as a result of the slow tectonic uplift with a low water table in the profile. The thick saprolite zone is formed covered with a thin limonite zone. Saprolite zone is dominated by serpentine minerals, goethite, smectite clays, and garnierite (mixed structure of hydrous $\mathrm{Ni}-\mathrm{Mg}$ silicates with a high content of Ni). Nickel is incorporated into saprolites by substitution of $\mathrm{Mg}$ in secondary serpentines. The usual content of $\mathrm{Ni}$ in silicate laterites is 2.0$3.0 \%$. Zones rich in garnierite can have up to $20 \%$ of $\mathrm{Ni}$.

Lateritic Ni/Co deposits are located mostly in the tropical areas, approximately 20 degrees north and south of the equator, but some lateritic deposits occur in the nontropical areas in Europe (Balkan peninsula and Ural mountain), Asia (Turkey, Kazakhstan) and USA (Oregon, California and North Carolina) [5, 6]. Lateritic ores usually contain between 0.8 and $3 \%$ of $\mathrm{Ni}$ and $0.1-0.2 \%$ of cobalt. Due to the high price of cobalt on the global metal market, the production of cobalt from laterites is economically feasible. These elements can be concentrated in any layer of the rock weathering profile:

- $\quad$ Limonite zone (1-1.7\% Ni, 0.1-0.2\% Co)

- Clay rich zone, sometimes designated as nontronite zone (1-5\% Ni, 0-0.05\% Co)

- $\quad$ Transition zone $(1.5-2 \% \mathrm{Ni}, 0.05-0.1 \% \mathrm{Co})$

- $\quad$ Saprolite zone $(2-3 \% \mathrm{Ni}, 0.05-0.1 \% \mathrm{Co})$

Pyrometallurgical processing of laterites (ferro-nickel and matte smelting) is suitable for lateritic ores consisted mostly of saprolitic zone. In order to have satisfactory yields of $\mathrm{Ni}$ the ore must meet some specific criteria, such as Fe/Ni ratio 12, Ni/Co ratio 40, and $\mathrm{SiO}_{2} / \mathrm{MgO}$ ratio 1.9. Ferro-nickel smelters require ores with $\mathrm{Ni}$ grade $>1.8 \%$. 
Pyrometallurgical nickel production from laterites follows conventional flow sheet, which includes upgrading of the ore in the mine, drying, calcining/reduction and smelting in the electric furnace in order to produce ferronickel or low-iron matte [1].

Hydrometallurgical approach for nickel and cobalt extraction can be applied for the treatment of all three types of the laterite ores.

\section{Hydrometallurgical processing of laterites}

Table 1 shows an overview of the hydrometallurgical technologies for the recovery of nickel from laterites. The technologies were selected based on their application on commercial or pilot scale and innovative potential. Some of the processes were applied on a large production scale (HPAL, Caron, and heap leaching), some of them are on the pilot-scale of production (Direct nickel, Neomet), and Ferredox process is the theoretical concept based on laboratory-scale research.

Table 1. Overview of the technologies for hydrometallurgical nickel extraction from laterites.

\begin{tabular}{|c|c|c|c|c|c|c|}
\hline Process & Ore type & Lixiviant & $\begin{array}{l}\text { Leaching } \\
\text { time }\end{array}$ & $\begin{array}{c}\text { Temperature, } \\
{ }^{\circ} \mathrm{C}\end{array}$ & $\begin{array}{l}\text { Pressure, } \\
\mathrm{kPa}\end{array}$ & $\begin{array}{c}\mathrm{Ni} \text { and } \mathrm{Co} \\
\text { extraction, } \\
\%\end{array}$ \\
\hline $\begin{array}{l}\text { High pressure } \\
\text { Acid Leaching } \\
\text { (HPAL) }\end{array}$ & Limonite & $\mathrm{H}_{2} \mathrm{SO}_{4}$ & $90 \mathrm{~min}$ & $245-250$ & 4000 & $90-95$ \\
\hline Caron process & Limonite & $\begin{array}{c}\mathrm{NH}_{3}- \\
\left(\mathrm{NH}_{4}\right)_{2} \mathrm{CO}_{3}\end{array}$ & n.a. & 850 & Ambiental & $80-85$ \\
\hline $\begin{array}{l}\text { Heap Leaching } \\
\text { (HL) }\end{array}$ & Saprolite & $\mathrm{H}_{2} \mathrm{SO}_{4}$ & $\begin{array}{c}120-150 \\
\text { days }\end{array}$ & Ambiental & Ambiental & $70-80$ \\
\hline $\begin{array}{l}\text { Atmospheric } \\
\text { Tank Leaching } \\
\text { (AL) }\end{array}$ & $\begin{array}{l}\text { Limonite and } \\
\text { saprolite }\end{array}$ & $\mathrm{H}_{2} \mathrm{SO}_{4}$ & 12 hours & 95 & Ambiental & $85-95$ \\
\hline Direct nikel & $\begin{array}{l}\text { Limonite and } \\
\text { saprolite }\end{array}$ & $\mathrm{HNO}_{3}$ & 2-4 hours & 105 & Ambiental & $>90$ \\
\hline $\begin{array}{l}\text { Ferredox } \\
\text { reductive } \\
\text { bioleaching } \\
\text { (concept) }\end{array}$ & Limonite & $\begin{array}{c}\mathrm{H}_{2} \mathrm{SO}_{4} \\
\text { acidophilic } \\
\text { bacteria }\end{array}$ & 7 days & 30 & Ambiental & $80-85$ \\
\hline $\begin{array}{l}\text { Hydrochloric } \\
\text { acid leaching } \\
\text { (Neomet } \\
\text { process) }\end{array}$ & $\begin{array}{l}\text { Limonite and } \\
\text { saprolite }\end{array}$ & $\mathrm{HCl}$ & n.a. & $100-110$ & Ambiental & $>95$ \\
\hline
\end{tabular}

\subsection{Caron process}

The Caron process, developed by professor Caron in the 1920s, is a hybrid between pyrometallurgy and hydrometallurgy. The limonite ore is roasted in order to selectively reduce $\mathrm{Ni}$ and $\mathrm{Co}$ to metal forms. These metals are then leached by ammonia/ammonium carbonate solution. A small amount of iron is reduced to form an alloy with $\mathrm{Ni}$ and $\mathrm{Co}$ [6-9]:

The roasting reaction at $850{ }^{\circ} \mathrm{C}$ : 


$$
\mathrm{NiO}_{2}+2 \mathrm{Fe}_{2} \mathrm{O}_{3}+3 \mathrm{H}_{2} \rightarrow \mathrm{FeNi}+\mathrm{Fe}_{3} \mathrm{O}_{4}+3 \mathrm{H}_{2} \mathrm{O}
$$
solution:

After cooling to $150-200{ }^{\circ} \mathrm{C}$ the ore is treated with ammonia/ammonium carbonate

$$
\mathrm{FeNi}+1.25 \mathrm{O}_{2}+2.5 \mathrm{H}_{2} \mathrm{O}+4 \mathrm{NH}_{3}+\left(\mathrm{NH}_{4}\right)_{2} \mathrm{CO}_{3} \rightarrow \mathrm{Ni}\left(\mathrm{NH}_{3}\right)_{6} \mathrm{CO}_{3}+\mathrm{Fe}(\mathrm{OH})_{3}
$$

After solid-liquid separation, the $\mathrm{Co}$ is recovered as cobalt sulfide, and $\mathrm{Ni}$ is recovered as nickel carbonate. The nickel carbonate is further calcined in order to produce a final product - nickel oxide.

$2 \mathrm{Ni}\left(\mathrm{NH}_{3}\right)_{6} \mathrm{CO}_{3}+\operatorname{steam}\left(\mathrm{H}_{2} \mathrm{O}\right) \rightarrow \mathrm{Ni}_{2}(\mathrm{OH})_{2} \mathrm{CO}_{3(s)}+12 \mathrm{NH}_{3}+\mathrm{CO}_{2}$

The Caron process is a well proven technology. Ammonia is recycled during the process, so the reagent costs are low and leaching step is highly selective for $\mathrm{Ni}$ and $\mathrm{Co}$. Recovery rates of $\mathrm{Ni}$ and Co can be relatively low in comparison to HPAL ( $<90 \% \mathrm{Ni}$, $<80 \% \mathrm{Co}$ ) and energy demand for ore roasting is very high which increases operating costs.

\subsection{High pressure acid leaching}

High pressure acid leaching (HPAL) is based on a sulfuric acid leaching of $\mathrm{Ni}$ and Co from laterites under elevated temperature $\left(240-270{ }^{\circ} \mathrm{C}\right)$ and pressure $(4000 \mathrm{kPa})$ in an autoclave. The rate of the chemical reaction is accelerated by high temperature and pressure. The leaching process is very efficient, as it finishes in just 60-90 minutes with $\mathrm{Ni}$ and Co recovery over $95 \%$. Iron precipitates as hematite during hydrolysis at temperatures more than $200^{\circ} \mathrm{C}$ in an acidic solution $(\mathrm{pH}=2-3)$, which reduces acid consumption and removes iron, preventing it from affecting $\mathrm{Ni}$ and Co separation from the pregnant leach solution.

Nickel and cobalt leaching reactions are:

$$
\begin{aligned}
& \mathrm{NiO}+\mathrm{H}_{2} \mathrm{SO}_{4} \rightarrow \mathrm{NiSO}_{4}+\mathrm{H}_{2} \mathrm{O} \\
& \mathrm{CoO}+\mathrm{H}_{2} \mathrm{SO}_{4} \rightarrow \mathrm{CoSO}_{4}+\mathrm{H}_{2} \mathrm{O}
\end{aligned}
$$

HPAL process is suitable for processing limonite ores since silicate and clay ores contain acid consuming gangue minerals, which affects the overall economy of the process. High acid consumption of $350-500 \mathrm{~kg}$ per ton of ore is one of the main disadvantages of the HPAL, so the profitability of the HPAL operations depends on the availability and price of the sulfuric acid. Also, capital costs for HPAL can be high. Because of the highly corrosive environment, expensive titanium lined autoclaves are required [6-10].

\subsection{Atmospheric acid leaching}

The limonite and saprolite ores are leached with concentrated sulfuric acid in stirred tanks at atmospheric pressure. The process is undertaken at $100{ }^{\circ} \mathrm{C}$, and leaching time is up to 12 hours using $2 \mathrm{~mol} / \mathrm{L} \mathrm{H}_{2} \mathrm{SO}_{4}$ and solid/liquid ratio of 0.1 . In the first step, the $\mathrm{Ni}$ and $\mathrm{Co}$ are leached from the limonitic ore, then the excess of sulfuric acid in the slurry is neutralized by the addition of the saprolite ore, releasing more $\mathrm{Ni}$ and $\mathrm{Co}$ into solution. The process can be applied to low-grade ores $(<1.5 \% \mathrm{Ni})$, and recoveries of $\mathrm{Ni}$ and $\mathrm{Co}$ are relatively high $(>90 \%$ for $\mathrm{Ni}$ and $>80 \% \mathrm{Co}$ ). The main disadvantages of this 
process are long leaching time and high acid consumption, higher in comparison to HPAL (500-700 kg per ton of ore) [7-10].

\subsection{Heap leaching}

Heap leaching with sulfuric acid was first investigated for the treatment of Greek laterites $[11,12]$ but further research showed that heap leaching could be applied for $\mathrm{Ni}$ and Co leaching from saprolitic ores from different parts of the world [1]. Recoveries of nickel are in the range of 65-85\% over 120-150 days with acid consumption of 200-600 $\mathrm{kg}$ per ton of ore. Relatively low capital and operational expenses are the main advantages of this process, but slow leaching rate and lower recoveries of $\mathrm{Ni}$ and $\mathrm{Co}$ are the main disadvantages $[7,10]$.

\subsection{Direct Nickel Process}

The Direct nickel process (DNP) is based on leaching of limonite and saprolite ores with nitric acid in stirred tanks at a temperature of $110^{\circ} \mathrm{C}$ and atmospheric pressure. The process was developed by Direct Nickel Group from Australia to treat laterite ores from Indonesia. The process is efficient, the leaching duration is 2-4 hours, and Ni and Co recoveries are $>95 \%$. All reagents used in this process are captured and reused $[6,8$, 9]. DNP is a more complex process involving several $\mathrm{pH}$ adjustments in the purification stage. Firstly, iron was removed during the hydrolysis process at a $\mathrm{pH}$ value between 2 and 3. This slurry is filtered, and the washed hematite filter cake is produced as a byproduct for sale. The iron-free solution is then treated with magnesia $(\mathrm{MgO})$ slurry to increase $\mathrm{pH}$ and precipitate aluminum hydroxide, which is filtered to produce an $\mathrm{Al}$ product. The low aluminum solution is now ready for mixed hydroxide precipitation where magnesia slurry is again used to raise $\mathrm{pH}$, in a two-stage circuit, and precipitate out the mixed hydroxide product (MHP), containing most of the nickel and cobalt recovered from the feed. Finally, the nitrogen oxide gases are recovered through a series of absorption stages where nitric acid is formed, which is then fed back into the leach circuit.

\subsection{Chloride leaching and Neomet Process}

Investigation of $\mathrm{HCl}$ leaching of $\mathrm{Ni}$ and Co from limonite ores began in the 1970s [10]. The most advanced chloride leaching technology is the Neomet Process developed by Canadian company Neomet Technologies. In this process hydrochloric acid is applied in order to leach $\mathrm{Ni}$ and $\mathrm{Co}$ from limonitic and saprolitic ores in tanks at atmospheric pressure and temperatures $100-110{ }^{\circ} \mathrm{C}$. The engineers of Neomet Technologies also developed a patented system to regenerate hydrochloric acid in the process using an ,atmospheric autoclave“. Ni and Co recoveries are reported to be high (>90\%) [13].

\subsection{Reductive bioleaching (Ferredox concept)}

Bioleaching is a well-proven technology applied for many years for heap bioleaching of copper from low-grade ores, and bio-oxidation of gold-bearing pyrite concentrates in stirred tanks [14]. Bioleaching of copper from low-grade ores is based on bacterially catalyzed oxidation of the copper sulfide minerals [15]. Bioleaching of nickel from laterites is based on a different approach: bacterial reduction of iron and manganese in iron and manganese oxide minerals $[16,17]$. Some species of heterotrophic and autotrophic acidophilic bacteria are facultative anaerobes. In anoxic environments, these bacteria can use $\mathrm{Fe}^{3+}$ instead of oxygen as a terminal acceptor of electrons in a respiratory chain reducing ferric $\left(\mathrm{Fe}^{3+}\right)$ to ferrous $\left(\mathrm{Fe}^{2+}\right)$ iron (equation 6) [18].

$$
24 \mathrm{Fe}^{3+}+\mathrm{C}_{6} \mathrm{H}_{12} \mathrm{O}_{6}+6 \mathrm{H}_{2} \mathrm{O} \rightarrow 24 \mathrm{Fe}^{2+}+6 \mathrm{CO}_{2}+24 \mathrm{H}^{+}
$$


Bridge and Johnson [19] discovered that acidophilic heterotroph Acidiphilium cryptum can induce reductive dissolution of iron oxide minerals (such as goethite and schwertmannite) in anoxic environments. Bacterially mediated dissolution of schwertmannite using glucose as electron donor can be represented by following chemical equation:

$$
3 \mathrm{Fe}_{8} \mathrm{O}_{8}(\mathrm{OH})_{6}\left(\mathrm{SO}_{4}\right)+\mathrm{C}_{6} \mathrm{H}_{12} \mathrm{O}_{6}+6 \mathrm{H}_{2} \mathrm{O} \rightarrow 24 \mathrm{Fe}^{2+}+6 \mathrm{CO}_{2}+3 \mathrm{SO}_{4}^{2-}+42 \mathrm{OH}^{-}
$$

A similar mechanism was applied for bioleaching of nickel from lateritic ores using iron-oxidizing acidophilic bacteria Acidithiobacillus ferrooxidans. In oxygen-rich environments, Acidithiobacillus ferrooxidans provides metabolic energy by oxidation of ferrous iron [20], but in the absence of oxygen, these bacteria switch to anaerobic metabolism using sulfur and reduced sulfur compounds as electron donors, and ferric iron as an electron acceptor. Equation 8 shows the reduction of ferric iron in goethite by Acidithiobacillus ferrooxidans using elemental sulfur as the electron donor [21]:

$6 \mathrm{FeOOH}+\mathrm{S}^{0}+10 \mathrm{H}^{+} \rightarrow 6 \mathrm{Fe}^{2+}+\mathrm{SO}_{4}^{2-}+8 \mathrm{H}_{2} \mathrm{O}$

After the dissolution of goethite matrix in the limonite ore which kept nickel atoms captured, nickel dissolves in the presence of sulfuric acid as nickel sulfate [22]:

$$
\mathrm{NiO}+\mathrm{H}_{2} \mathrm{SO}_{4} \rightarrow \mathrm{NiSO}_{4}+\mathrm{H}_{2} \mathrm{O}
$$

Cobalt is often associated with manganese oxyhydroxides of the asbolanelithiophorite group. Asbolane can be dissolved by the reductive activity of Acidithiobacillus ferrooxidans:

$$
\mathrm{Mn}_{3} \mathrm{O}_{3}(\mathrm{OH})_{6}+\mathrm{S}^{0}+2 \mathrm{H}_{2} \mathrm{SO}_{4} \rightarrow 3 \mathrm{MnSO}_{4}+5 \mathrm{H}_{2} \mathrm{O}
$$
sulfate:

After the dissolution of asbolane, cobalt oxide dissolves in sulfuric acid as cobalt

$$
\mathrm{Co}_{2} \mathrm{O}_{3}+3 \mathrm{H}_{2} \mathrm{SO}_{4} \rightarrow \mathrm{Co}_{2}\left(\mathrm{SO}_{4}\right)_{3}+3 \mathrm{H}_{2} \mathrm{O}
$$

Du Plesis et al. [22] proposed Ferredox process for $\mathrm{Ni}$ and $\mathrm{Co}$ anaerobic reductive bioleaching from limonitic laterites.

The reductive bioleaching process operates at a temperature of $30{ }^{\circ} \mathrm{C}$ and a mild acidic condition ( $\mathrm{pH}$ 1.7-2), so in comparison to other hydrometallurgical approaches for $\mathrm{Ni}$ and Co extraction from laterites (except heap leaching), this process would consume less energy and require equipment made of cheaper materials, so the capital and operational expenses of the Ferredox process might be relatively low. The economy of the process is affected by sulfur and sulfuric acid consumption. The Ferredox process has not been tested on a pilot production scale yet.

\section{Overview of the hydrometallurgical operations for $\mathrm{Ni}$ and Co extraction from lateritic ores}

Table 2 shows an overview of global operations for hydrometallurgical production of $\mathrm{Ni}$ and $\mathrm{Co}$ from lateritic ore deposits. Since the situation on the market changes very fast, some of the presented data can be obsolete. The last Caron process operation in 
Yabulu (Australia) was closed in 2016, so the only commercially applied hydrometallurgical processes for nickel and cobalt extraction from laterites are HPAL and heap leaching.

Table 2. Global operations for hydrometallurgical production of Ni and Co from lateritic ores.

\begin{tabular}{|c|c|c|c|c|}
\hline Project & Country & Technology & $\begin{array}{l}\text { Planned annual } \mathrm{Ni} \\
\text { production, kt }\end{array}$ & References \\
\hline Ravensthorpe & Australia & HPAL & 25 & \multirow{3}{*}{ [6] } \\
\hline Meta nickel & Turkey & HPAL & 20 & \\
\hline Murrin Murrin & Australia & HPAL & 40 & \\
\hline Goro & New Caledonia & HPAL & 60 & \multirow{6}{*}[23]{} \\
\hline Ambatovy & Madagascar & HPAL & 60 & \\
\hline Ramu & $\begin{array}{l}\text { Papua New } \\
\text { Guinea }\end{array}$ & HPAL & 33 & \\
\hline Taganito & Philippines & HPAL & 36 & \\
\hline Coral Bay & Philippines & HPAL & 24 & \\
\hline Gördes & Turkey & HPAL & 10 & \\
\hline Piaui & Brazil & Heap leaching & 22 & \multirow{8}{*}[1]{} \\
\hline NiWest & Australia & Heap leaching & 14 & \\
\hline Cerro Matoso & Colombia & Heap leaching & 20 & \\
\hline Caldag & Turkey & Heap leaching & 20 & \\
\hline Pearl & Indonesia & Heap leaching & 32 & \\
\hline Gag Island & Indonesia & Heap leaching & 27.3 & \\
\hline Cleopatra & USA & Heap leaching & 21.5 & \\
\hline Acoje & Philippines & Heap leaching & 24.5 & \\
\hline
\end{tabular}

The final product of HPAL and heap leaching is $\mathrm{NiSO}_{4}$, which is used mostly for production of the batteries. Increasing global demand for batteries stimulates investment in hydrometallurgical plants for production of the Ni from lateritic ores. The economy of the hydrometallurgical plants is improved by cobalt production, which is lost in pyrometallurgical operations. HPAL provides fast leaching and excellent recovery rate of $\mathrm{Ni}$ and Co, but technology is complex and sensitive to failures. Many HPAL operations worldwide suffered from long rump-up delays and, consequently, high capital investments, often billions of dollars higher than initially planned [23, 1]. Operational expenses of the HPAL process are comparable to pyrometallurgical operations, and in some cases, are significantly higher [1]. Many HPAL operations are not making a profit and survive with the help of subsidies of the local governments, thus providing employment in undeveloped regions and supply of the strategically important metals [3]. On the other hand, heap leaching technology is relatively simple, and capital and operational expenses are significantly lower in comparison to HPAL and pyrometallurgy, but the leaching rate is very slow. Taking into account long delays in rump-up of almost all HPAL plants in the world and difficulties to achieve planned production capacities, tortoise sometimes could be faster than Achilles. Approximately $80 \%$ of nickel from lateritic deposits is produced pyrometallurgically [23], but the possibility to produce cobalt and some other valuable chemical elements from laterites could make the hydrometallurgical approach more attractive. For example, some lateritic deposits contain rare earth elements (REE) and scandium [24, 25]. Nancucheo et al. [25] used reductive 
bioleaching in order to successfully extract rare earth elements (REE) from Brazilian lateritic ore, which contains monazite, the main REE-bearing phosphate mineral.

\section{Conclusion}

Global nickel production is swinging from production based on nickel sulfide minerals to production based on lateritic ore deposits. Although nickel and cobalt can be successfully extracted from lateritic ores by application of hydrometallurgical technologies, pyrometallurgy is still dominant technology for their extraction from laterites. The hydrometallurgy usually cannot compete with pyrometallurgy with respect to the efficiency of the process. High-pressure acid leaching (HPAL) is a hydrometallurgical technology for nickel extraction from laterites which can compete with pyrometallurgy, but capital and operational expenses are also comparable to pyrometallurgical operations. Investors are more likely to invest their money in wellproven technology, like smelters. Many HPAL operations failed or suffered from long rump-up delays, huge unplanned capital expenses and inability to reach planned annual production. So, the cautiousness of the investors is understandable. The hydrometallurgical technology for the treatment of laterites should be relatively simple, with significantly lower capital and operational expenses in comparison to HPAL and pyrometallurgy, with a high recovery rate of $\mathrm{Ni}$ and $\mathrm{Co}$ (and possibly other valuable elements) and reasonable leaching time. The sulfuric acid heap leaching mostly corresponds to the previous description, but leaching time is too long. The investigations of the reductive heap bioleaching of lateritic ores are at the beginning, and literature data is lacking. The catalytic role of the bacteria might significantly speed up the leaching process in comparison to leaching with sulfuric acid only. This might be the most promising approach to develop a hydrometallurgical process for $\mathrm{Ni}$ and Co recovery from lateritic deposits. The new challenge is also recovery of scandium (about $100 \mathrm{ppm}$ ) from lateritic ore using hydrometallurgical operations: high-pressure leaching in an autoclave, solvent extraction, and precipitation process.

\section{Acknowledgments}

The authors are grateful to the Ministry of Education, Science and Technological Development of the Republic of Serbia for the financial support (contract 451-03$68 / 2020-14 / 200023$ ) of this investigation.

\section{References}

[1] A. Oxley, M.E. Smith, O. Caceres: Miner Eng, 88 (2016) 53-60.

[2] A. Dalvi, G. Bacon, R. Osborne: The past and the future of nickel laterites, PDAC 2004 International Convention, Trade Show and Investors Exchange, March 2004.

[3] M. Elias: Nickel Laterite Deposits-Geological Overview, Resources and Exploitation. Centre for Ore Deposit Research, University of Tasmania, Special Publication, 4 (2002) 205-220.

[4] N.W. Brand, C.R.M. Butt, M.Elias: AGSO journal of Australian geology \& geophysics, 17 (1998) 81-88.

[5] E.E. Marsh and E.D. Anderson: Ni-Co laterite deposits, U.S. Geological Survey Open-File Report 2011-1259, (2011) 9p.

[6] S. Stopić, B. Friedrich: Mil Tech Cour, 64 (2016) 1033-1047. 
[7] J. Kyle: Nickel laterite processing technologies - where to next? In: ALTA 2010 Nickel/Cobalt/Copper Conference Proceedings, Perth, WA, Australia, 2010 May,

[8] A. Taylor: Technical \& Cost Comparison of Laterite Treatment Processes Part 1. In: ALTA 2014 Proceedings, Perth, WA, Australia: 2014 May, pp. 35-46.

[9] M. Dry: Technical \& Cost Comparison of Laterite Treatment Processes Part 2. In: ALTA 2014 Proceedings, Perth, WA, Australia: 2014 May, pp. 47-65.

[10] R.G. MacDonald and B.I. Whittington: Hydrometallurgy, 91 (2008) 35-55.

[11] N. Panagiotopoulos, S. Agatzini, A. Kontopoulos: Extraction of nickel and cobalt from serpentinic type laterites by atmospheric pressure sulphuric acid leaching. In Proceedings of the Technical Sessions at the 115th TMS-AIME Annual Meeting, New Orleans, LA, USA, 2-6 March 1986p. A86-30.

[12] K. Komnitsas, E. Petrakis, O. Pantelaki, A. Kritikaki: Minerals, 8 (2018) 377.

[13] B. Harris and C. White: Recent Developments in the Chloride Processing of Nickel Laterites. In: ALTA 2011 Nickel/Cobalt/Copper Conference Proceedings, Perth, WA, Australia 2011 May, pp. 12-24.

[14] J.D. Batty and G.V. Rorke: Hydrometallurgy, 83 (2006) 83-89.

[15] A. Schippers and W. Sand: Appl Environ Microbiol, 65 (1999) 319-321.

[16] D.B. Johnson, B.M. Grail, K.B. Hallber: Minerals, 3 (2013) 49-58.

[17] I. Nancucheo, B.M. Grail, F. Hilario, C. Du Plesis, D.B. Johnson: Appl Microbiol Biotechnol, 98 (2014) 6297-6305.

[18] K. Coupland, D.B. Johnson: FEMS Microbiol Lett, 279 (2008) 30-35.

[19] T.A.M. Bridge and D.B. Johnson: Geomicrobiol J, 17 (2000) 193-206.

[20] J. Valdés, I. Pedroso, R. Quatrini, R.J. Dodson, H. Tettelin, R. Blake, J.A. Eisen, D.S. Holmes: BMC Genom, 9 (2008) 597.

[21] D.B. Johnson and C.A. du Plesis: Miner Eng, 75(2015) 2-5.

[22] C.A. Du Plesis, W. Slabbert, K.B. Hallberg, D.B. Johsnon: Ferredox: Hydrometallurgy, 109 (2011) 221-229.

[23] J. Gabb, HPAL: Upping the pressure, Global Mining Research, March 2018. www.globalminingresearch.com

[24] Ş. Kaya and Y. A. Topkaya, High pressure acid leaching of a nickel laterite ore to extract scandium. In: ERES 2014- 1st International Conference on European Rare Earth Resources. 2015. Milos Island, Greece: Heliotopos Conferences Ltd.

[25] I. Nancucheo, G. Oliveira, M. Lopes, D.B. Johnson: Minerals, 9 (2019) 136.

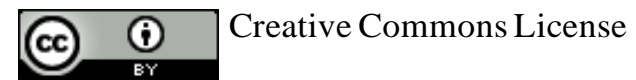

This work is licensed under a Creative Commons Attribution 4.0 International License. 